\title{
A reexamination of the interpretations of errors in formal syllogistic reasoning
}

\author{
JAMES J. ROBERGE, Temple University, \\ Philadelphia, $\mathrm{Pa} .1912$
}

One hundred eleven college $S$ s selected conclusions for 59 syllogisms. These syllogisms varied according to premise pair. figure, and validity status. The results indicated a remarkable consistency in patterns of error preference, regardless of validity status, with all of the preferred errors being accounted for by either atmosphere effect and probabilistic inference or invalid conversion and probabilistic inference.

Many psychologists (e.g., Morgan \& Morton, 1944; Miller, 1951) refer to the "atmosphere effect," first proposed by Woodworth \& Sells (1935), and later revised by Sells (1936), as a plausible explanation of error in the syllogistic reasoning of adults. In their original formulation, Woodworth and Sells postulated the general hypothesis that the atmosphere of the premises, be it affirmative 1 or negative, universal or particular, creates a sense of validity for the corresponding conclusion. Thus, for example, an affirmative premise such as "All Xs are Ys" or "Some Xs are Ys" (A or I) produces an affirmative atmosphere. Similarly, a universal premise such as "All $\mathrm{Xs}$ are Ys" or "No Xs are Ys" (A or E) produces a universal atmosphere. In addition, since syllogisms have two premises, they formulated two secondary hypotheses. These were: (1) If either premise is a particular premise, then a particular atmosphere is produced, and (2) if either premise is a negative premise, then a negative atmosphere is produced. Woodworth and Sells also introduced a "principle of caution," which Sells incorporated in his reformulation of the atmosphere effect, stating that Ss tend to accept weak and guarded rather than strong conclusions. Finally, woodworth \& Sells (1935) and Sells (1936) provided empirical data that substantiated these hypotheses for syllogisms having invalid conclusions. However, only minimal evidence was presented for syllogisms having valid conclusions. Furthermore, since some of the syllogisms that Sells classified as invalid involved premise pairs and figures, which by logical convention are valid, any interpretation of his results with regard to the validity status of the syllogisms is impossible.
Morgan \& Morton (1944) found that Ss presented with syllogisms involving abstract symbols or concrete words with little or no personal significance had difficulty in selecting correct conclusions and usually based their conclusions on the structure of the syllogisms rather than upon deductive inference. Thus, for the most part, their results supported the atmosphere hypotheses. Chapman \& Chapman (1959), on the other hand, showed that the error preferences of Ss could be explained by "reasoning behavior which often leads to correct solutions of everyday problems but which is disallowed in the traditional rules of the syllogism [p. 226]." Specifically, these error preferences could be explained by invalid conversion and probabilistic inference. Recently, Begg \& Denny (1969) presented a unified restatement of the atmosphere hypotheses in terms of the quality, i.e., affirmative or negative, and the quantity, i.e., universal or particular, of the premises of the syilogism. In addition, they attempted to reconcile the empirical differences for the IE, EO, and OE premise pairs found in previous studies by gathering new data. However, in the interpretation of their results they erroneously concluded that "the results, in terms of preferred error frequency ... are clearly and without exception in accord with predictions based on the restated principles of the atmosphere effect [pp. 353-354]." More precisely, in the data that they presented for the $O E$ premise pair, the error frequencies for the $\mathrm{E}$ and $\mathrm{O}$ alternatives were equal, whereas the predicted error preference was 0 .

The present investigation represented an attempt to replicate and extend the findings of previous studies, particularly those of the Chapman and Chapman study. This was accomplished by the development of a syllogism test comprised of items for all premise pairs and figures for which no valid conclusion is possible or only one valid conclusion is possible. The inclusion of items involving premise pairs and/or figures not included in the instruments used in most previous studies increased the generalizability of the findings and permitted comparisons according to the validity status of the syllogisms.

\section{SUBJECTS}

The Ss were 111 graduate students in educational psychology at Temple
University who had had no formal training in logic.

\section{MATERIALS}

A syllogism test ${ }^{2}$ consisting of 59 items was constructed by the author. These 59 items represent all premise pairs and figures for which no valid conclusion is possible or only one valid conclusion is possible. A complete listing of the premise pairs figures, and validity statuses of the items is shown in Table 1. Each item contained two premises and five alternative conclusions, e.g., suppose that

\section{No $\mathrm{Ys}_{\mathrm{s}}$ are $\mathrm{Zs}$}

Some $\mathrm{Xs}$ are $\mathrm{Zs}$

then
(1) No Xs are Ys
(2) Some Xs are Ys
(3) No valid conclusion is possible
(4) Some Xs are not Ys
(5) All Xs are Ys

The correct alternative for 45 of the items was "No valid conclusion is possible"; the correct alternative for the other 14 items was one of the other four alternatives.

To avoid extraneous influences on responses, premises involving letters $(X, Y$, or $Z$ ) were used and the order of presentation of the 59 items was randomized. In addition, the five alternatives were randomly assigned to the five positions, with the restriction that each alternative appeared as equally often as possible in each position. Similarly, the variables $(\mathrm{X}, \mathrm{Y}$, or $\mathrm{Z}$ ) were randomly assigned as major, minor, or middle terms, with the restriction that each variable appeared approximately the same number of times as each type of term.

The instructions gave an example of an AE second figure syllogism and specified the task as marking the one correct alternative from among the five choices. Moreover, the instructions contained a discussion of the meaning of the word "some" according to the conventions of formal logic whereby "some" means "at least one" (Copi, 1961, p. 136).

\section{RESULTS AND DISCUSSION}

The percentages of Ss choosing each alternative for the various premise pairs and figures are shown in Table 1. In addition, the validity status of each syllogism, the keyed alternative, and the chi-square value for the error preference distribution are presented. The mean accuracy percentage for the invalid syllogisms was $32 \%$, while that for the valid syllogisms was $51 \%$. However, any generalizations about the relative difficulty 
of valid and invalid syllogisms are unwarranted, since the correct alternative for most of the valid syllogisms is also the atmosphere prediction. Furthermore, the question of relative difficulty is inextricably interwoven with that of syllogistic figure (Frase, 1968). The mean accuracy percentage for the invalid syllogisms was approximately equi to that for the smaller subset of invalid syllogisms used by Morgan and Morton. Moreover, it was approximately $10 \%$ higher than that for the smaller subset of invalid syllogisms used by Chapman and Chapman, and approximately $20 \%$ higher than that for the similar set of invalid syllogisms used by Begg and Denny. A possible explanation for these differences is suggested by the nature of the correct response for the invalid syllogisms. In the present study and in the Morgan and Morton study, the correct alternatives for these syllogisms were "No valid conclusion is possible" and "None of the conclusions seems to follow logically," respectively. In the Chapman and Chapman study, the correct alternative for these syllogisms was "None of these." In the Begg and Denny study, on the other hand, Ss were instructed to put a question mark next to those items for which no correct alternative appeared. Thus these results suggest that as the vagueness of the correct response increased, the difficulty of the invalid syllogisms increased. The mean accuracy percentage for the valid syllogisms was approximately $10 \%$ less than that for the smaller subset of valid syllogisms used by Morgan and Morton. However, since valid syllogisms were used only as "filler" items in most studies and no data was presented for them, no further comparisons were possible.

The pattern of error preferences for the invalid syllogisms was remarkably similar to that reported by Chapman and Chapman. For each of the premise pairs, except IE and OE, Ss were attracted to one of the four erroneous conclusions. Moreover, the chi-square values for all but four of the invalid syllogisms were greater than 16.27, indicating that the distributions of error preferences for these syllogisms were significantly $(\mathrm{p}<.001)$ greater than chance.

Referring to the atmosphere hypotheses as originally proposed by Woodworth and Sells, and later restated by Begg and Denny, we find, as Chapman and Chapman did, that this set of hypotheses was not supported by the data for the IE and OE premise pairs, on each of which the predicted error was $\mathrm{O}$. However, Chapman and Chapman found that the preferred error for the IE and OE premise pairs was $E$, whereas the data for the present study indicated that $\mathrm{E}$ and $\mathrm{O}$ were the preferred errors for these premise pairs and that they
Table 1

Percentages of Ss Selecting Each Alternative

\begin{tabular}{|c|c|c|c|c|c|c|c|c|c|}
\hline Item & Premises & Figure & Valid & A & $\mathbf{E}$ & I & 0 & $\mathrm{~N}^{\mathrm{a}}$ & $x^{2}$ \\
\hline $\begin{array}{l}29 \\
26 \\
34\end{array}$ & $\begin{array}{l}\text { AA } \\
\text { AA } \\
\text { AA }\end{array}$ & $\begin{array}{l}\text { II } \\
\text { III } \\
\text { IV }\end{array}$ & $\begin{array}{l}\text { No } \\
\text { Yes } \\
\text { Yes }\end{array}$ & $\begin{array}{l}50 \\
53 \\
57\end{array}$ & $\begin{array}{l}5 \\
3 \\
5\end{array}$ & $\begin{array}{c}8 \\
25+ \\
25+\end{array}$ & $\begin{array}{l}1 \\
0 \\
4\end{array}$ & $\begin{array}{c}35+ \\
19 \\
9\end{array}$ & $\begin{array}{l}108.78^{* * *} \\
106.45^{* * *} \\
115.60^{* * *}\end{array}$ \\
\hline $\begin{array}{r}4 \\
46\end{array}$ & $\begin{array}{l}\mathrm{AE} \\
\mathrm{AE}\end{array}$ & $\begin{array}{l}\text { I } \\
\text { III }\end{array}$ & $\begin{array}{l}\text { No } \\
\text { No }\end{array}$ & $\begin{array}{l}3 \\
5\end{array}$ & $\begin{array}{l}65 \\
57\end{array}$ & $\begin{array}{l}2 \\
7\end{array}$ & $\begin{array}{l}5 \\
8\end{array}$ & $\begin{array}{l}26+ \\
23+\end{array}$ & $\begin{array}{l}172.73 * * * \\
107.02 * * *\end{array}$ \\
\hline $\begin{array}{l}27 \\
37\end{array}$ & $\begin{array}{l}\text { EA } \\
\text { EA }\end{array}$ & III & $\begin{array}{l}\text { Yes } \\
\text { Yes }\end{array}$ & $\begin{array}{l}3 \\
1\end{array}$ & $\begin{array}{l}55 \\
58\end{array}$ & $\begin{array}{l}3 \\
5\end{array}$ & $\begin{array}{l}23+ \\
24+\end{array}$ & $\begin{array}{l}17 \\
13\end{array}$ & $\begin{array}{l}104.70^{* * *} \\
121.62^{* * *}\end{array}$ \\
\hline $\begin{array}{r}1 \\
15 \\
48 \\
42\end{array}$ & $\begin{array}{l}\mathrm{AI} \\
\mathrm{AI} \\
\mathrm{AI} \\
\mathrm{Al}\end{array}$ & $\begin{array}{l}\text { I } \\
\text { II } \\
\text { III } \\
\text { IV }\end{array}$ & $\begin{array}{l}\text { Yes } \\
\text { No } \\
\text { Yes } \\
\text { No }\end{array}$ & $\begin{array}{l}1 \\
0 \\
8 \\
5\end{array}$ & $\begin{array}{l}2 \\
4 \\
4 \\
3\end{array}$ & $\begin{array}{l}85+ \\
66 \\
69+ \\
59\end{array}$ & $\begin{array}{r}11 \\
12 \\
9 \\
15\end{array}$ & $\begin{array}{l}2 \\
18+ \\
10 \\
18+\end{array}$ & $\begin{array}{c}19.00^{* * *} \\
155.07^{* * *} \\
3.41 \\
114.67^{* * *}\end{array}$ \\
\hline $\begin{array}{l}35 \\
25 \\
20 \\
49\end{array}$ & $\begin{array}{l}\text { IA } \\
\text { IA } \\
\text { IA } \\
\text { IA }\end{array}$ & $\begin{array}{l}\text { I } \\
\text { II } \\
\text { IV }\end{array}$ & $\begin{array}{l}\text { No } \\
\text { No } \\
\text { Yes } \\
\text { Yes }\end{array}$ & $\begin{array}{l}3 \\
4 \\
5 \\
6\end{array}$ & $\begin{array}{l}5 \\
6 \\
5 \\
4\end{array}$ & $\begin{array}{l}66 \\
58 \\
70+ \\
69+\end{array}$ & $\begin{array}{r}12 \\
13 \\
8 \\
12\end{array}$ & $\begin{array}{c}15+ \\
19+ \\
12 \\
9\end{array}$ & $\begin{array}{c}138.70^{* * *} \\
106.82^{* * *} \\
4.70 \\
5.29\end{array}$ \\
\hline $\begin{array}{r}32 \\
24 \\
5 \\
59\end{array}$ & $\begin{array}{l}\text { AO } \\
\text { AO } \\
\text { AO } \\
\text { AO }\end{array}$ & $\begin{array}{l}\text { I } \\
\text { II } \\
\text { III } \\
\text { IV }\end{array}$ & $\begin{array}{l}\text { No } \\
\text { Yes } \\
\text { No } \\
\text { No }\end{array}$ & $\begin{array}{l}1 \\
2 \\
4 \\
3\end{array}$ & $\begin{array}{l}2 \\
7 \\
7 \\
4\end{array}$ & $\begin{array}{l}23 \\
17 \\
25 \\
14\end{array}$ & $\begin{array}{l}59 \\
62+ \\
41 \\
57\end{array}$ & $\begin{array}{l}16+ \\
12 \\
23+ \\
22+\end{array}$ & $\begin{array}{c}115.82^{* * *} \\
14.95^{* *} \\
50.95^{* * *} \\
116.14^{* * *}\end{array}$ \\
\hline $\begin{array}{l}50 \\
12 \\
28 \\
39\end{array}$ & $\begin{array}{l}\text { OA } \\
\text { OA } \\
\text { OA } \\
\text { OA }\end{array}$ & $\begin{array}{l}\text { I } \\
\text { II } \\
\text { III } \\
\text { IV }\end{array}$ & $\begin{array}{l}\text { No } \\
\text { No } \\
\text { Yes } \\
\text { No }\end{array}$ & $\begin{array}{l}2 \\
2 \\
3 \\
1\end{array}$ & $\begin{array}{r}6 \\
10 \\
5 \\
5\end{array}$ & $\begin{array}{r}9 \\
25 \\
14 \\
26\end{array}$ & $\begin{array}{l}65 \\
48 \\
72+ \\
53\end{array}$ & $\begin{array}{c}18+ \\
15+ \\
6 \\
15+\end{array}$ & $\begin{array}{c}143.59^{* * *} \\
64.55^{* * *} \\
10.16^{*} \\
91.02^{* * *}\end{array}$ \\
\hline $\begin{array}{l}17 \\
38 \\
31 \\
33\end{array}$ & $\begin{array}{l}\mathrm{EE} \\
\mathrm{EE} \\
\mathrm{EE} \\
\mathrm{EE}\end{array}$ & $\begin{array}{l}\text { I } \\
\text { II } \\
\text { III } \\
\text { IV }\end{array}$ & $\begin{array}{l}\text { No } \\
\text { No } \\
\text { No } \\
\text { No }\end{array}$ & $\begin{array}{r}10 \\
10 \\
9 \\
7\end{array}$ & $\begin{array}{l}31 \\
16 \\
22 \\
32\end{array}$ & $\begin{array}{l}5 \\
3 \\
1 \\
3\end{array}$ & $\begin{array}{l}5 \\
2 \\
3 \\
1\end{array}$ & $\begin{array}{l}50+ \\
69+ \\
65+ \\
57+\end{array}$ & $\begin{array}{l}39.57^{* * *} \\
19.88^{* * *} \\
34.21^{* * *} \\
66.17^{* * *}\end{array}$ \\
\hline $\begin{array}{r}16 \\
2 \\
40 \\
11\end{array}$ & $\begin{array}{l}\text { EI } \\
\text { EI } \\
\text { EI } \\
\text { EI }\end{array}$ & $\begin{array}{l}\text { I } \\
\text { II } \\
\text { III } \\
\text { IV }\end{array}$ & $\begin{array}{l}\text { Yes } \\
\text { Yes } \\
\text { Yes } \\
\text { Yes }\end{array}$ & $\begin{array}{l}1 \\
0 \\
1 \\
2\end{array}$ & $\begin{array}{l}18 \\
32 \\
23 \\
31\end{array}$ & $\begin{array}{r}12 \\
7 \\
6 \\
9\end{array}$ & $\begin{array}{l}60+ \\
45+ \\
46+ \\
42+\end{array}$ & $\begin{array}{r}9 \\
16 \\
24 \\
16\end{array}$ & $\begin{array}{l}16.91 * * * \\
44.77^{* * *} \\
33.60^{* * *} \\
35.00^{* * *}\end{array}$ \\
\hline $\begin{array}{l}19 \\
56 \\
54 \\
47\end{array}$ & $\begin{array}{l}\text { IE } \\
\text { IE } \\
\text { IE } \\
\text { IE }\end{array}$ & $\begin{array}{l}\text { I } \\
\text { II } \\
\text { III } \\
\text { IV }\end{array}$ & $\begin{array}{l}\text { No } \\
\text { No } \\
\text { No } \\
\text { No }\end{array}$ & $\begin{array}{l}4 \\
5 \\
6 \\
5\end{array}$ & $\begin{array}{l}35 \\
33 \\
26 \\
23\end{array}$ & $\begin{array}{r}10 \\
7 \\
12 \\
11\end{array}$ & $\begin{array}{l}20 \\
25 \\
28 \\
37\end{array}$ & $\begin{array}{l}32+ \\
30+ \\
28 t \\
25+\end{array}$ & $\begin{array}{l}36.74 * * * \\
36.97 * * * \\
21.00^{* * *} \\
36.28 * * *\end{array}$ \\
\hline $\begin{array}{r}9 \\
43 \\
30 \\
13\end{array}$ & $\begin{array}{l}\text { EO } \\
\text { EO } \\
\text { EO } \\
\text { EO }\end{array}$ & $\begin{array}{l}\text { I } \\
\text { II } \\
\text { III } \\
\text { IV }\end{array}$ & $\begin{array}{l}\text { No } \\
\text { No } \\
\text { No } \\
\text { No }\end{array}$ & $\begin{array}{l}0 \\
3 \\
1 \\
1\end{array}$ & $\begin{array}{r}15 \\
9 \\
13 \\
22\end{array}$ & $\begin{array}{r}15 \\
14 \\
8 \\
14\end{array}$ & $\begin{array}{l}37 \\
28 \\
35 \\
25\end{array}$ & $\begin{array}{l}32+ \\
45+ \\
44+ \\
39+\end{array}$ & $\begin{array}{l}45.48 * * * \\
28.12^{* * *} \\
49.10^{* * *} \\
24.40^{* * *}\end{array}$ \\
\hline $\begin{array}{r}57 \\
58 \\
8 \\
36\end{array}$ & $\begin{array}{l}O E \\
O E \\
O E \\
O E\end{array}$ & $\begin{array}{l}\text { I } \\
\text { II } \\
\text { III } \\
\text { IV }\end{array}$ & $\begin{array}{l}\text { No } \\
\text { No } \\
\text { No } \\
\text { No }\end{array}$ & $\begin{array}{l}4 \\
6 \\
4 \\
3\end{array}$ & $\begin{array}{r}22 \\
14 \\
21 \\
6\end{array}$ & $\begin{array}{l}15 \\
13 \\
15 \\
14\end{array}$ & $\begin{array}{l}16 \\
20 \\
17 \\
30\end{array}$ & $\begin{array}{l}43+ \\
47+ \\
43+ \\
47+\end{array}$ & $\begin{array}{l}13.51^{* *} \\
7.79 \\
12.77^{* *} \\
36.62^{* * *}\end{array}$ \\
\hline $\begin{array}{l}10 \\
23 \\
51 \\
21\end{array}$ & $\begin{array}{l}\text { II } \\
\text { II } \\
\text { II } \\
\text { II }\end{array}$ & $\begin{array}{l}\text { I } \\
\text { II } \\
\text { III } \\
\text { IV }\end{array}$ & $\begin{array}{l}\text { No } \\
\text { No } \\
\text { No } \\
\text { No }\end{array}$ & $\begin{array}{l}2 \\
2 \\
1 \\
5\end{array}$ & $\begin{array}{l}3 \\
3 \\
5 \\
3\end{array}$ & $\begin{array}{l}50 \\
41 \\
26 \\
40\end{array}$ & $\begin{array}{l}17 \\
15 \\
12 \\
17\end{array}$ & $\begin{array}{l}29+ \\
39+ \\
57+ \\
35+\end{array}$ & $\begin{array}{l}93.10^{* * *} \\
74.24^{* * *} \\
38.33^{* *} \\
58.11^{* * *}\end{array}$ \\
\hline $\begin{array}{r}41 \\
3 \\
14 \\
7\end{array}$ & $\begin{array}{l}10 \\
10 \\
10 \\
10\end{array}$ & $\begin{array}{l}\text { I } \\
\text { II } \\
\text { III } \\
\text { IV }\end{array}$ & $\begin{array}{l}\text { No } \\
\text { No } \\
\text { No } \\
\text { No }\end{array}$ & $\begin{array}{l}1 \\
4 \\
3 \\
2\end{array}$ & $\begin{array}{l}1 \\
5 \\
5 \\
7\end{array}$ & $\begin{array}{l}19 \\
13 \\
17 \\
20\end{array}$ & $\begin{array}{l}35 \\
37 \\
36 \\
39\end{array}$ & $\begin{array}{l}44+ \\
42+ \\
40+ \\
32+\end{array}$ & $\begin{array}{l}64.71^{* * *} \\
55.88^{* * *} \\
52.10^{* * *} \\
53.05^{* * *}\end{array}$ \\
\hline $\begin{array}{r}53 \\
52 \\
44 \\
6 \\
55 \\
22 \\
45 \\
18 \\
\end{array}$ & $\begin{array}{l}\mathrm{Ol} \\
\mathrm{OI} \\
\mathrm{OI} \\
\mathrm{OI} \\
\mathrm{OO} \\
\mathrm{OO} \\
\mathrm{OO} \\
\mathrm{OO}\end{array}$ & $\begin{array}{l}\text { I } \\
\text { II } \\
\text { III } \\
\text { IV } \\
\text { I } \\
\text { II } \\
\text { III } \\
\text { IV }\end{array}$ & $\begin{array}{l}\text { No } \\
\text { No } \\
\text { No } \\
\text { No } \\
\text { No } \\
\text { No } \\
\text { No } \\
\text { No }\end{array}$ & $\begin{array}{l}1 \\
1 \\
5 \\
3 \\
2 \\
2 \\
4 \\
2\end{array}$ & $\begin{array}{l}2 \\
6 \\
4 \\
3 \\
5 \\
5 \\
7 \\
5\end{array}$ & $\begin{array}{l}14 \\
18 \\
15 \\
23 \\
16 \\
15 \\
10 \\
15\end{array}$ & $\begin{array}{l}48 \\
33 \\
36 \\
38 \\
31 \\
26 \\
25 \\
41\end{array}$ & $\begin{array}{l}35+ \\
41+ \\
41+ \\
34+ \\
46+ \\
52+ \\
54+ \\
38+\end{array}$ & $\begin{array}{l}98.56^{* * *} \\
46.94^{* * *} \\
50.97^{* * *} \\
58.89^{* * *} \\
41.33^{* * *} \\
34.47^{* * *} \\
26.26^{* * *} \\
66.83^{* * *}\end{array}$ \\
\hline
\end{tabular}

Note-The chi-square values were calculated on the frequency data. $a_{N}$ designates the alternative "No valid conclusion is possible."

+ indicates the keyed alternative.

$* p<.05, \quad * * p<.01, * * * p<.001$

varied in attractiveness according to and Chapman study. Rather, the syllogistic figure. Furthermore, for the EO atmosphere prediction, $O$, was the premise pair, the error preferences were preferred error.

not equally divided between the $\mathrm{E}$ and $\mathrm{O}$ These results for the IE, OE, and EO alternatives as they were in the Chapman premise pairs can be explained by 
probabilistic inference (Cohen \& Nagel, 1934; Chapman \& Chapman, 1959). In the case of an IE premise pair, perhaps Ss reason that since the subject and predicate terms do not share the middle term, then a negative conclusion is appropriate. Thus, for example, if "Some Xs are Ys" and "No $\mathrm{Zs}$ are $\mathrm{Ys}$," the $\mathrm{Ss}$ reason that the middle term, $Y$, is not shared and, therefore, either "Some Zs are not Xs" or "No Zs are Xs." In the case of an O premise, e.g., "Some Xs are not Ys," coupled with an E premise, e.g., "No Zs are Ys," perhaps Ss accept the subcontrary of the $\mathrm{O}$ premise, i.e., "Some $\mathrm{Xs}$ are Ys," and reason as above. Finally, in the case of an E premise coupled with an O premise, the Ss again accept the subcontrary of the $O$ premise and as a result reason with an EI premise pair for which $O$ is a valid conclusion in any figure. The data (see Table 1) for the IE, OE, and EO premise pairs supported these explanations.

The results also revealed that Sells' revised formulation of the atmosphere hypotheses, i.e., including the principle of caution, was less effective than the Woodworth and Sells formulation in that it failed to predict the preferred error for $\mathrm{AA}, \mathrm{AE}$, and $\mathrm{EE}$ premise pairs in addition to those mentioned above. Most of the differences in the results of the present study and those reported by Sells can be attributed to variations in test format. Specifically, Sells used a true-false format that artificially inflated the error preferences for particular conclusions from universal premises.

The pattern of error preferences for many of the valid syllogisms revealed no noticeable piling up on any one of the four erroneous conclusions. In fact, the distribution of error preferences for some of the valid syllogisms was not significantly greater than chance $(p>.05)$. More importantly, however, the pattern of error preferences for valid and invalid syllogisms involving the same premise pair (AA, AI, IA, AO, OA) were markedly similar. A scrutiny of Table 1 reveals that the only difference in response preference for these syllogisms was that for the keyed alternative. This can be interpreted as indicating that $S s$ who recognized the valid conclusions also recognized the invalid conclusions and that the atmosphere effect was operative to a marked degree with valid syllogisms. Alternatively, these results can be interpreted as providing empirical evidence to support the hypothesis of invalid conversion which Chapman and Chapman used to explain error preference for invalid syllogistic figures that yield a valid conclusion in at least one other figure.

Finally, the results for both valid and invalid syllogisms indicated that in those cases where either an $\mathrm{I}$ or $\mathrm{O}$ alternative was the primary error preference, the other of the two alternatives was the secondary error preference (except for the EO and OE premise pairs). Moreover, the order of the premises seemed to have little bearing upon the acceptance of erroneous conclusions. For example, $\mathrm{AI}$ and IA premise pairs yielded similar patterns of error preference for both valid and invalid syllogisms.

In general, the results of this investigation confirmed those reported by previous investigators (e.g., Woodworth \& Sells, 1935; Morgan \& Morton, 1944; Chapman \& Chapman, 1959; Begg \& Denny, 1969) for invalid syllogisms, and they extended these findings to include valid syllogisms. Furthermore, these results indicated that either the atmosphere hypotheses, as originally proposed by Woodworth and Sells, and probabilistic inference or the hypothesis of invalid conversion and probabilistic inference accurately predicted error preference for all premise pairs. Thus, future research on errors in formal syllogistic reasoning should focus on the examination of Ss' protocols rather than on the study of error preference patterns.

\section{REFERENCES}

BEGG, I., \& DENNY, J. P. Empirical reconciliation of atmosphere and conversion interpretations of syllogistic reasoning errors. Journal of Experimental Psychology, 1969, 81, 351-354.

CHAPMAN, L. J., \& CHAPMAN, J. P. Atmosphere effect re-examined. Journal of Experimental Psychology, 1959, 58, 220-226. COHEN, M. R., \& NAGEL, E. An introduction to logic and scientific method. New York: Harcourt, Brace, \& World, 1934.

COPI, I. M. Introduction to logic. New York: Macmillan, 1961.

FRASE, L. T. Associative factors in syllogistic reasoning. Journal of Experimental Psychology, 1968, 76, 407-412.

MILLER, G. A. Speech and language. In S. S. Stevens (Ed.), Handbook of experimental psychology. New York: Wiley, 1951. Pp. 789-810.

MORGAN, J. J. B., \& MORTON, J, T. The distortion of syllogistic reasoning produced by personal convictions. Joumal of Social Psychology, 194, 20, 39-59.

SELLS, S. B. The atmosphere effect: An personal convictions. Journal of Social Psychology, 1944, 20, 39-59.

WOODWORTH, R. S., \& SELLS, S. B. An atmosphere effect in formal syllogistic reasoning. Journal of Experimental Psychology, 1935, 18, 451-460.

\section{NOTES}

1. There are four different standard forms of categorical propositions used in syllogisms: (1) Name-Universal affirmative; expression-all Ss are Ps; symbol-A. (2) Name-Universal negative; expression-no $\mathrm{Ss}$ are $\mathrm{Ps}$; symbol-E. (3) Name-Particular affirmative; expression-some $\mathrm{Ss}$ are $\mathrm{Ps}$; symbol-I. (4) Name-Particular negative; expression-some Ss are not Ps; symbol-O. The figures of the syllogism are the four possible arrangements of the terms in the major and minor premises, where $\mathrm{S}$ is the subject of the conclusion (minor term), $\mathrm{P}$ is the predicate of the conclusion (major term), and $M$ is the middle term.

$\begin{array}{llll}\text { Fig. } 1 & \text { Fig. } 2 & \text { Fig. } 3 & \text { Fig. } 4\end{array}$

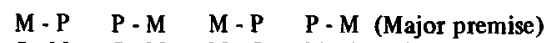
$\underline{S-M} \quad \underline{S-M} \quad \underline{M-S} \quad \underline{M-S}$ (Minor premise) S-P S-P S-P S-P (Conclusion)

2. Requests for copies of the test should be sent to the author at the Department of Educational Psychology, Temple University, Philadelphia, $\mathrm{Pa} .19122$. 